LIMA, Elizabeth Maria Freire de Araújo; PELBART, Peter Pál. Arte, clínica e loucura: um território em mutação. História, Ciências, Saúde - Manguinhos, Rio de Janeiro, v.14, n.3, p.709-735, jul.-set. 2007.

\section{Arte, clínica e loucura: um território em mutação*}

\section{Art, medical treatment and insanity: a territory in flux}

\section{Elizabeth Maria Freire de Araújo Lima}

Docente do curso de Terapia Ocupacional da Faculdade de Medicina da Universidade de São Paulo. Coordenadora do Laboratório de Estudos e Pesquisa Arte e Corpo em Terapia Ocupacional Rua Cipotânea, 51 - Cidade Universitária 05360-160 São Paulo - SP Brasil beth.lima@usp.br

\section{Peter Pál Pelbart}

Professor do Departamento de Filosofia da Pontifícia Universidade Católica de São Paulo e do Programa de Estudos Pós-graduados em

Psicologia Clínica da PUC-SP. Coordenador da Cia. Teatral Ueinzz.

Rua Ministro Godói, 969 - 4º andar

Sala 4 A-01 - Perdizes

05015-901 São Paulo - SP Brasil

ppelbart@uol.com.br
A experiência clínica e didática no campo da terapia ocupacional, na qual práticas artísticas e processos terapêuticos se atravessavam, levou-nos à realização de uma pesquisa histórica visando investigar como se constituíram, no Brasil, as relações entre os campos da saúde mental e da arte, a partir de meados do século XIX e durante o século XX. Os métodos utilizados para realizar esta pesquisa - que tem como horizonte teórico o pensamento de Foucault, Deleuze e Guattari foram a cartografia e a arqueologia. Com a arqueologia, tratamos dos discursos e acontecimentos históricos, procurando as forças que os engendraram. Ao cartografar, buscamos acompanhar algumas linhas que, emergindo de cada um desses campos em relação ao outro, se cruzaram formando diferentes configurações no território em estudo.

PALAVRAS-CHAVE: arte; clínica; loucura; terapia ocupacional; saúde mental; Brasil.

LIMA, Elizabeth Maria Freire de Araújo; PELBART, Peter Pál. Art, medical treatment and insanity: a territory in flux.

História, Ciências, Saúde - Manguinhos, Rio de Janeiro, v.14, n.3, p.709-735, July-Sept. 2007.

Based on a combination of clinical and pedagogical experience in occupational therapy, which interlinks artistic practices and therapeutic processes, we carried out a historical study designed to investigate how the fields of mental health and art became interrelated in Brazil between the mid 19th and 20th centuries. The methods used for this research, which is underpinned by the thinking of Foucault, Deleuze and Guattari, were cartography and archeology. We used archeology to investigate the historical discourses and events, seeking out the forces behind them. Through cartography we sought to map out some lines which, emerging from each of these fields in relation to the other, intersect to form different patterns in the area under study.

KEYWORDS: art; medicine; insanity; occupational therapy; mental health; Brazil. 
*Este artigo foi produzido a partir da tese de doutorado Das obras aos

procedimentos:

ressonâncias entre os campos da arte e da terapia ocupacional, apresentada ao Programa de Estudos Pós-graduados em Psicologia Clínica da PUC/SP em 2003. Alguns resultados da pesquisa que aqui abordamos foram apresentados no $9^{\circ}$ Congresso Brasileiro de História da Medicina - $3^{\text {o }}$ Encontro em História da Medicina Mental e Saberes Afins, promovido pela Casa de Oswaldo Cruz/ Fiocruz, no Rio de Janeiro, em novembro de 2004.
A presentamos neste artigo os resultados de uma pesquisa resultante de uma experiência na qual práticas clínicas e práticas estéticas se atravessavam, levando-nos a investigar as relações entre os campos da saúde mental e da arte. Em texto intitulado "A arte não revela a verdade da loucura, a loucura não detém a verdade da arte", Teixeira Coelho (2002) afirma que Arte \& Loucura foi uma questão da modernidade, que com ela findou. Para o autor, a trama que uniu arte moderna, psicologia e loucura foi tecida pelas imagens que os psicólogos extraíram da arte moderna para iluminar a loucura e pelas leituras que os artistas fizeram dos estudos psicológicos para construir sua estética. "Os estudiosos da loucura foram assíduos freqüentadores das exposições da vanguarda artística e os artistas modernos liam insistentemente as descrições modernas da loucura" (p.150). De uma ou outra forma, segundo Coelho, essa intrincada trama já se desfez; sua legitimidade cultural e suas ressonâncias já se distanciam de nós. Diante das obras contemporâneas, nos diz o autor, a reação das pessoas já não é considerá-las 'coisas de loucos', e sim tachá-las de mau gosto, lixo. Para Coelho, "Arte \& loucura não é mais uma questão cultural porque, alterando uma proposição de Michel Foucault, percebe-se hoje nitidamente que a loucura nunca poderá enunciar a verdade da arte, assim como nunca a arte terá como enunciar a verdade da loucura" (p.161).

Concordamos com essas considerações no que diz respeito à idéia de que um campo não diz a verdade do outro. Mas será que hoje outras ressonâncias se fazem presentes entre arte e loucura? Pensar que não é em qualquer configuração histórica que o universo da arte se compõe com o da clínica ou o da loucura nos faz desnaturalizar essa relação, que pode muitas vezes nos parecer familiar e até corriqueira, e nos leva a pensar que marca essa relação ganha em nosso tempo. Nesse sentido, cabe perguntar como teria se produzido esse território que, na modernidade, fez se atravessarem arte, clínica e loucura, e se a forma como as linhas da arte, da clínica e da loucura se articularam na modernidade ainda faz sentido hoje. Se não o faz, estariam as possíveis conexões entre esses campos hoje encerradas? Ou será que houve uma transformação na relação entre os campos que, em vez de desfazer esse território, o teria encaminhado para novas configurações, produzindo uma mutação em sua paisagem? Se assim for, que nova paisagem começa a se desenhar no contemporâneo? Essas questões nos guiaram no percurso deste estudo. Para tentar respondê-las realizamos uma pesquisa histórica visando explorar o território que foi se constituindo no Brasil, a partir de meados do século XIX e durante o século XX, à medida que arte, clínica e loucura começaram a dialogar. Esse território possui amplas conexões com o surgimento da terapia ocupacional brasileira e tem em primeiro plano a psiquiatria, as instituições asilares e o uso da ocupação nessas instituições. 
1 Os personagens conceituais são, segundo Deleuze e Guattari (2001), um tipo psicossocial que torna perceptíveis as formações de território, os vetores de desterritorialização e os processos de reterritorialização de um dado campo social em determinada época. Seus movimentos e modos de existência "se tornam suscetíveis de uma determinação que os arranca dos estados de coisas históricos de uma sociedade como vivido dos indivíduos, para fazer acontecimentos do pensamento sobre o plano que ele traça ou sobre os conceitos que ele cria" (p.93).
Os métodos utilizados para realizar a pesquisa - que tem como horizonte teórico o pensamento de Foucault, Deleuze e Guattari foram a cartografia e a arqueologia. Com a arqueologia, tratamos dos discursos e dos acontecimentos históricos, procurando as forças que os engendraram. Ao cartografar, buscamos produzir um desenho que pudesse acompanhar os movimentos de composição e desmancho das diferentes paisagens presentes no território que nos propusemos a explorar. Para Rolnik (1989, p.15),

Paisagens psicossociais também são cartografáveis. A cartografia neste caso acompanha e se faz ao mesmo tempo em que o desmanchamento de certos mundos - sua perda de sentido - e a formação de outros mundos que se criam para expressar afetos contemporâneos, em relação aos quais os universos vigentes se tornam obsoletos.

Com a cartografia buscamos explorar o território e acompanhar algumas linhas que emergiram de cada um dos campos em direção aos outros. Essas linhas são obras, trajetórias e experimentações na fronteira entre os campos, realizadas por artistas, 'doentes', loucos, médicos e terapeutas. No acompanhamento dessas experiências e personagens históricos paradigmáticos - tomados aqui como personagens conceituais ${ }^{1}$ - encontramos diferentes configurações históricas nas quais clínica, arte e loucura, ao se atravessarem, desenharam múltiplas paisagens.

A primeira dessas configurações compreende o final do século XIX, momento da constituição das primeiras instituições asilares no Brasil, quando a arte não era vista como instrumento terapêutico nem como apoio para o estabelecimento de concepções teóricas ou diagnósticas, embora o campo da arte já começasse a se interessar pela medicina mental e pelos estados mentais alterados. Para desvendar essa paisagem nos faremos acompanhar de dois criadores: QorpoSanto e Machado de Assis. O segundo momento refere-se às primeiras décadas do século $X X$, quando as práticas ergoterápicas, a psiquiatria, a psicanálise e a arte brasileira entram em relações de atravessamento, fazendo emergir um território que começa a ser visitado por artistas, clínicos e pacientes. Aqui visitaremos as experiências de um médico psiquiatra e também crítico de arte, Osório César, e de um artista moderno, Flávio de Carvalho. Para explorar a terceira paisagem, mapeada em torno das décadas de 1940 e 1950, que apresenta importante inflexão no pensamento sobre as contribuições da arte para a clínica e sobre as relações entre arte e subjetividade, dialogaremos com Nise da Silveira e Mário Pedrosa. No texto que segue buscaremos delinear essas diferentes paisagens, finalizando com apontamentos que nos abrem para as configurações que as relações entre esses campos vêm produzindo no contemporâneo. 


\section{A emergência de um território: arte, clínica e loucura esboçam uma paisagem}

Como vimos, nos encaminhamos para esta pesquisa histórica por compreender que não é em qualquer configuração sociocultural que o universo da arte se compõe com o universo da clínica. Foucault (1995) nos conta que, em hospitais no mundo árabe criados por volta do século XII e destinados exclusivamente aos loucos -, a música, a dança, os espetáculos e as narrativas de contos fabulosos eram utilizados como forma de intervenção e de cura da alma. Na Europa, durante a Renascença, a retomada de conhecimentos e práticas da Antiguidade e o interesse pela loucura infiltrado em todas as esferas da vida cultural e na arte em especial -, somaram-se à influência árabe fazendo surgir os primeiros hospitais para insanos, nos quais essa tradição estava presente: as artes, em especial a música, tinham aí virtudes terapêuticas que atuavam na totalidade do ser humano, penetrando-lhe corpo e alma.

Mas, ao longo do século XVII, o que Foucault (1995) chamou de experiência trágica da loucura foi sendo relegado à penumbra, dando lugar privilegiado a uma consciência crítica da loucura. Esta passou a ser percebida não mais como uma estranheza familiar do mundo, mas no horizonte social da pobreza, da incapacidade para o trabalho, da impossibilidade de integrar-se ao grupo e por fim como doença mental (p.78). Foi o nascimento da experiência clássica da loucura que a reduziu ao silêncio.

Foi então que a música e as artes em geral desertaram das práticas terapêuticas, o que coincidiu com a criação dos hospícios organizados em torno do tratamento moral, cujo principal aliado era um trabalho estruturado e bem dirigido. Nesse contexto, os romances, as histórias, os espetáculos teatrais e a música passaram a ser vistos como meios de perversão de toda a sensibilidade, desregramento dos sentidos, cultivo das ilusões, produtores, enfim, das doenças nervosas e mentais. (Foucault, 1995, p.37, 368). Assim, a clínica, no início de sua forma moderna, desinteressou-se pela arte, e um silêncio ocupou o espaço entre esses dois campos. Um silêncio que coincidiu com o silêncio ao qual foi condenada a loucura por toda a época clássica. Mas foi dessa região do silêncio, que se concretizou no internamento, que a loucura pôde, segundo Foucault, conquistar uma linguagem que era sua. O reaparecimento da loucura no domínio da linguagem precedeu qualquer interesse da clínica pela arte, seja como aliada para a construção de uma teoria do funcionamento psíquico, seja como instrumento de procedimentos terapêuticos.

Esse movimento estava inserido num conjunto de profundas transformações no pensamento ocidental, em curso no final do século XIX, apontando para uma tentativa de fazer dialogar duas 
formas de conhecimento que haviam sido mantidas em separado: de um lado uma vertente de conhecimento científico, mecanicista e causal; de outro, uma forma de conhecimento intuitivo e estético. Segundo Arantes (1996), nesse período, em que ocorria, no campo da arte, a revolução impressionista, a sensibilidade ocidental se alargava, voltando sua atenção para tudo aquilo que, de alguma forma, contrariava a supremacia da norma culta européia e a idéia clássica do progresso que ela pressupunha. Nesse alargamento da sensibilidade, a prática artística dirigiu-se para a exploração daquilo que lhe era exterior, visando a pesquisa de novas formas de fazer arte e buscando operar no limite da linguagem artística e do sistema da arte. Entre esses campos de exterioridade, a arte explorou sua vizinhança com a loucura, tanto no processo de criação do artista quanto no interesse por aquilo que alguns sujeitos, enredados nas malhas de instituições asilares, produziam. Assim, as relações entre arte, clínica e loucura passaram a se esboçar a partir da confluência entre dois deslocamentos: de um lado, buscando conquistar uma linguagem, alguns habitantes do mundo da loucura faziam um movimento quase imperceptível - já que oriundo de um espaço de exclusão e silêncio - em direção à criação artística; de outro, alguns artistas, ao se debruçarem sobre a alma humana e suas vicissitudes e buscando ampliar os limites de sua linguagem, voltavam seu olhar para o mundo da loucura.

No Brasil, encontramos dois criadores exemplares desses dois movimentos e dos quais trataremos de forma breve: Qorpo-Santo e Machado de Assis. Este último está entre os escritores que, durante o século XIX, tomaram a loucura como questão e tema, buscando uma linguagem que pudesse dialogar com a experiência do desatino. Muitas vezes esse interesse acabou por levá-lo a querelas com a psiquiatria. Trata-se de uma "querela interpretativa", nas palavras de Elisabeth Roudinesco (8 abr. 2001), que ao longo do século XIX opôs alienistas a escritores na tentativa de formular uma compreensão para o fenômeno da loucura. Uma querela que evidenciava uma oposição entre o reino da razão - que se debatia em tentativas de explicar, classificar, distinguir o comportamento normal do patológico e excluir a loucura - e o reino da paixão, do sentimento e da imaginação que, acolhendo a loucura, fazia que ela passasse a habitar nossos íntimos recônditos.

Aos olhos do século XX, os escritores parecem ter sido mais felizes que a ciência psiquiátrica em encontrar uma linguagem que pudesse expressar a experiência da loucura. Para Lobo (1993, p.98), autores como Dostoiévsky e Machado de Assis apresentam a loucura, o descoroamento e a reviravolta do mundo instituído na própria ruptura do discurso narrativo e no esfacelamento da verdade narrativa através das vozes de inúmeros personagens. De fato, a obra de Machado de Assis é exemplar a esse respeito. Em seus tex- 
tos, principalmente naqueles escritos a partir de 1880, as personagens perdem a coerência e sua complexidade as desvia de certo padrão de normalidade. Através da construção de suas personagens, o escritor buscava explorar singularidades, pequenas diferenças, quase ínfimas expressões de vida, o que configurava uma sensibilidade para tratar das questões da loucura. Machado gostava, como ele mesmo dizia, de "catar o mínimo e o escondido. Onde ninguém mete o nariz, aí entra o meu, com a curiosidade estreita e aguda que descobre o encoberto" (Machado de Assis, citado em Teixeira, 1987, p.59). Essa característica revelaria uma capacidade de focalizar detalhes, o que o levaria a se orgulhar até mesmo de sua miopia (Gledson, 1998).

Além disso, o tema da loucura, o lugar que essa experiência ocupava na sociedade de seu tempo, as tênues fronteiras que a separavam da razão, mas também a exploração de singularidades e pequenas diferenças foram uma preocupação constante do escritor. No conto "O alienista", o centro temático é justamente a discussão em torno da norma, de sua existência, de sua busca, da delimitação entre loucura e razão. Através desse conto, a literatura nos oferece uma análise precisa e contundente, mas também extremamente satírica e irônica, do que era a prática psiquiátrica em seu início. Com seu interesse pela exploração da alma humana, sua fineza e leveza no trato das questões mais complexas, Machado de Assis foi capaz de revelar certas experiências da loucura e descortinar os mecanismos de poder em jogo nas relações entre o Estado e a ciência psiquiátrica (Assis, 1977).

Afora o interesse dedicado ao mundo da loucura, podemos depreender da obra de Machado a idéia de que a literatura pode ser pensada como clínica no sentido que Deleuze (1997) dá a esse termo quando vê o romancista como médico de si mesmo e do mundo e a literatura como um empreendimento de saúde. Em 1908, Machado escreve: "a arte é o remédio e o melhor deles" (carta a Mário de Alencar, 23 fev. 1908, citada em Lopes, 2001, p.43). No conto "Terpsícore", nome da musa da dança, Machado de Assis fez aparecer a dança como a possibilidade para que um casal pobre saia da miséria e de uma vida medíocre, ao encontrar nessa arte o encantamento, certa riqueza na existência. Condenados a um cotidiano voltado apenas para o trabalho, sem um dia para o descanso, sabendo que "isto é mau para a saúde", o "par de malucos" (Assis, 1996, p.41, 33) escolhe gastar o dinheiro para dar espaço ao desejo nascido com a dança, quando, por obra da sorte e do acaso, são contemplados com um prêmio de loteria. O que, num primeiro momento, parece delírio ou loucura, acaba por revelar que, na experiência de um movimento ritmado e expressivo e no mergulho em formas inventivas de existência - para além da necessidade de subsistência -, cria-se a possibilidade de sair da condição de escravo 
2 Expressão utilizada por Mário Pedrosa.

3 A noção de acontecimento, em Foucault, indica a irrupção de uma singularidade única e aguda que esgarça o tecido da história instaurando temporalidades divergentes. para dançar livremente (Arrigucci Jr., 1996, p.18). Machado de Assis nos apresenta, nesse conto, a dança e a experimentação dos corpos, do ritmo e do movimento como meio de escavar uma saída de formas de vida aprisionantes, condenadas à mesmice e a um lugar de desvalor.

Se em Machado de Assis a busca de uma saída pela via da arte aparece no espaço da ficção, outros artistas, no seu interesse pelo mundo da loucura, flagraram pessoas que ocupavam espaço de desvalor ou de exclusão empreendendo esse movimento, essa busca de uma saída. Ana Mae Barbosa nos conta que, no século XVIII, alguns artistas adentravam os asilos e faziam deles desenhos de observação. Em alguns desses registros encontramos loucos desenhando; em outros, desenhos nas paredes das celas. "Os artistas foram, portanto, os primeiros a chamar a atenção para o desenho dos loucos em seus próprios desenhos" (Barbosa, 1998, p.10).

É importante salientar que os internos desses asilos buscavam formas de expressão ou de criação independentemente de qualquer proposta terapêutica a eles dirigida. Assim, antes de ser uma atividade terapêutica indicada aos pacientes, e sem ser uma produção artística que viesse necessariamente a transitar de alguma forma pelo circuito cultural, os atos de pintar, escrever e desenhar estavam presentes, talvez como necessidade $v$ tal $^{2}$, na existência de muitos dos que habitavam esses tristes lugares que eram (e são) os hospitais psiquiátricos.

E um acontecimento ${ }^{3}$ desse tipo que encontramos em QorpoSanto, sua história e sua obra, Ensiqlopédia ou seis mezes de huma enfermidade, produzida no final do século XIX. A história de um criador (não era em seu tempo tomado como artista), um homem precário, na designação de Flávio Aguiar (1975), que conheceu o primeiro manicômio brasileiro bem como a experiência do estigma de louco e que, desse lugar, produziu uma obra que permaneceu por cem anos esquecida. A história dessa obra - na qual encontramos o esforço de um homem para criar um plano de consistência através da escrita -, do momento de sua produção até chegar ao seu destino, o leitor; os caminhos tortuosos que trilhou para chegar até nós, no século XXI, seus aparecimentos e desaparecimentos; a luta de um corpo para inscrever sua criação nos circuitos da cultura, publicá-la, enviá-la à posteridade, fazê-la viver para além de si mesmo e buscar seus interlocutores.

Há um inextrincável entrelaçamento entre a vida do escritor e a obra que produziu, entre força e precariedade, indistintamente articuladas. Aos 35 anos, em 1864, Qorpo-Santo sofreu a primeira intervenção da justiça, que solicitou um exame de sua sanidade mental. A partir daí houve um longo processo até sua interdição em 1868. Os detalhes do processo ele mesmo nos conta, tendo publicado em seu livro VII documentos sobre sua interdição e os autos dos exa- 
4 As frases entre aspas destre trecho são versos de poemas de Qorpo-Santo, respectivamente: "Produções" (QorpoSanto, 1877, livro I, p.69); "Rapidez" (Qorpo-Santo, 1877, livro I, p.57); "O Marquês d'Olinda" (Qorpo-Santo, 2000, p.216). mes de sanidade mental nele realizados, reproduzidos no livro organizado por Guilhermino César (Qorpo-Santo, 1969). Nesse período, no qual se batia contra a psiquiatria e a patologização de seu modo de existência, Qorpo-Santo entregou-se a uma atividade literária febril. Em 1877 (não se sabe como) conseguiu autorização para abrir a Tipografia Qorpo-Santo e imprimir sua obra. O resultado é uma produção caudalosa e desconexa, organizada em nove tomos, composta de versos, relatos, provérbios e pequenas peças teatrais, que apresentam uma vastíssima visão de mundo (QorpoSanto, 1877). A grande quantidade de material, somada à sua história, fez dele uma lenda conservada na tradição oral e que se imortalizou na figura de homem excêntrico, quase ridículo, forjada pelos cronistas da época: um doido que havia escrito poesias de doido que ninguém leu.

Há algo que grita em sua produção: o quanto era importante para Qorpo-Santo o ato da escrita - "sublime ou não irá escripto!". O que interessava para ele não era a suposta qualidade do trabalho, mas o fato mesmo de escrever. "Mel e fel" estavam presentes, e o que mais importava era a ajuda que a escrita podia oferecer para "manter-se numa altura digna". ${ }^{4}$ E para além desse ato solitário da escrita e do valor inestimável desta por possibilitar-lhe a manutenção de certa consistência, havia um ambiente povoado de destinatários para quem a obra foi enviada. Qorpo-Santo parecia ansiar por uma interlocução.

Escrever lhe era extremamente importante, mas publicar também, buscar seu público, partilhar sua criação. No momento em que foi produzida, essa obra não teve praticamente nenhuma repercussão. Nenhuma repercussão no meio literário e artístico, mas também nenhuma repercussão - é importante ressaltar - nos meios psiquiátricos. Naquele tempo não havia ainda uma grade teórica que articulasse loucura e arte. Se nos pautarmos pelos documentos produzidos pelos médicos pelos quais passou, mencionados pelo próprio Qorpo-Santo no volume VII de sua Ensiqlopedia, podemos concluir que seus escritos e seu trabalho na tipografia não foram pensados, sob nenhuma ótica, como atividade terapêutica. Entre os procedimentos técnicos levados a cabo nas instituições psiquiátricas naquele período, as atividades artísticas não tinham lugar.

Talvez só o próprio Qorpo-Santo tenha vislumbrado uma relação entre a produção de seus escritos, sua 'enfermidade' e a produção de certa saúde, já que designava sua Ensiqlopédia como uma "panacéia para todos os males" (Qorpo-Santo, 1877, citado em Marques, 1993, p.13) e escrevia: "As minhas enfermidades trazemme um tríplice melhoramento: mais saber, mais força, mais poder!" (Qorpo-Santo, 2000, p.319). Ou, 


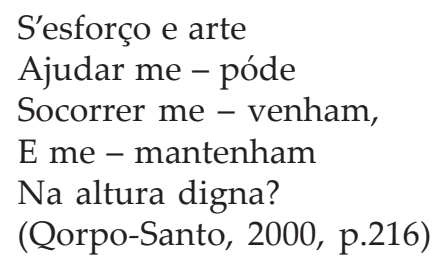

Dessa forma, foi à revelia de todos que Qorpo-Santo deu corpo a sua criação que jorrava, ao que parece de forma incessante e excessiva, premida pela sua "ingrata e nojenta imaginação" (QorpoSanto, 1877, citado em Marques, 1993, p.3). No esforço que empreendeu para editar sua obra vemos o movimento de um homem que endereça ao futuro sua criação: "Que pensarão os vindouros do que penso, escrevo e faço?" (Qorpo-Santo, 1877, citado em Marques, 1993, p.3). Marques nos conta que Qorpo-Santo calculou um século para a legibilidade de seus textos. De fato, a leitura da obra de QorpoSanto transformou-se no decorrer de quase um século e meio: a posteridade lhe dedicaria um lugar de destaque na produção teatral brasileira, muitas vezes colocando-o entre os loucos geniais.

Cercado de sarcasmo, descaso ou indiferença, Qorpo-Santo buscou, através de sua obra, seu público num povo por vir.

\section{A paisagem moderna ocupa o território no qual se atravessam arte, clínica e loucura}

Artistas e criadores voltavam seu olhar e interesse para o universo da loucura e pessoas que transitavam por esse universo realizavam um movimento em direção à recuperação de uma linguagem que lhe fosse própria. Mas algo se passava para além de um mero paralelismo entre essas duas figuras, a do artista e a do louco. Os artistas começavam a trabalhar em uma inquietante vizinhança com a loucura. Foram muitos os criadores que correram o risco de desabar nos abismos da loucura, levando suas experimentações artísticas a regiões em que obra e subjetividade se confundiam. Era uma nova experiência da linguagem e das coisas que se estava fazendo e que inscrevia, no seio da criação, um face-a-face entre arte e loucura.

Localizadas em direções opostas do espaço cultural, arte e loucura estavam, ao mesmo tempo, muito próximas pela situação limite que ocupavam na orla exterior da cultura, porta-vozes de uma desmedida que poderia colocar em xeque essa mesma cultura. É por isso que, para Foucault (1995), a partir do século XIX a loucura está associada ao que há de decisivo para o mundo moderno em toda obra, e também àquilo que toda obra comporta de mortífero, de constrangedor, de inoperância. Para esse autor, Nietzsche, Artaud e Van Gogh, ao acolherem a loucura, deram-lhe uma expressão e uma ascendência sobre o mundo ocidental. Essa confluência entre loucura e arte 


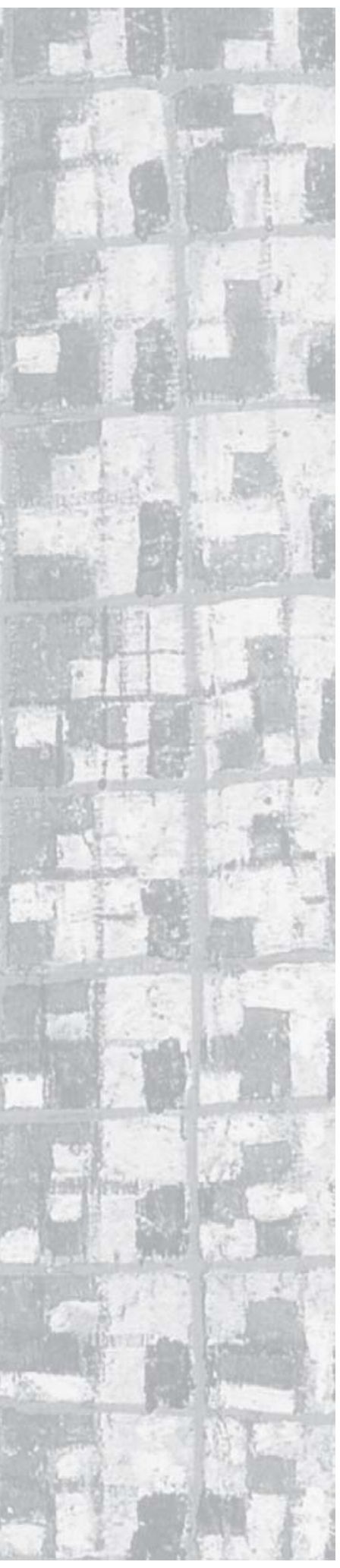

não passou despercebida para o pensamento psiquiátrico. E a psiquiatria começou a se interessar pelas manifestações artísticas dos doentes mentais, inicialmente tentando tomar os processos de criação e as obras produzidas nesse processo como elementos que iriam se compor na construção de um conhecimento sobre o funcionamento psíquico e seus estados alterados ou patológicos.

Na Europa, a tônica dos primeiros trabalhos sobre o tema publicados no final do século XIX estava na análise psicopatológica das produções plásticas e na busca de um modelo que permitisse correlacionar características de estilo a diferentes formas patológicas. Segundo Karl Jaspers (1883-1969), o olhar do psiquiatra examinava as obras essencialmente pelo valor sintomatológico, utilizando-as como recurso auxiliar ao diagnóstico (Lafora, 1927). Em 1907, Réja chamou a atenção, pela primeira vez, para a proximidade entre aquilo que se considerava a verdadeira criação artística e os desenhos de alguns doentes (Lafora, 1927). Em 1922, outro psiquiatra, Hans Prinzhorn, estudou e organizou toda a produção francesa e alemã encontrada até então acerca da produção artística dos doentes mentais e publicou um livro que se tornou referência para os principais autores brasileiros que trabalhariam com o tema.

Estudos produzidos no campo psiquiátrico sobre as expressões artísticas dos doentes mentais chegaram ao Brasil concomitantemente às primeiras referências ao pensamento psicanalítico e à arte moderna européia. As práticas laborterápicas desenvolvidas nos manicômios receberam os sopros desses ventos que varriam a vida cultural em nosso país, e um procedimento antropofágico possibilitou que as influências européias nesses três campos fossem deglutidas de forma a fazê-las misturarem-se e interferirem-se mutuamente, fazendo emergir em nosso cenário a trama moderna que articulou arte, clínica e loucura. Essa trama pautou-se pelo estabelecimento da relação entre a produção artística e os processos inconscientes e foi marcada pela vizinhança que se instaurava entre a produção dos artistas modernos e aquela encontrada nos manicômios. No entanto, essa proximidade entre arte moderna e loucura e as relações entre arte e inconsciente foram tomadas de formas diferentes e com efeitos muito diversos.

Para alguns a proximidade entre a produção moderna e aquela encontrada nos asilos poderia ser tomada como comprovação do valor estético das produções dos loucos. É o que aparece no trabalho de Osório César, músico, psiquiatra e crítico de arte que via na arte um caminho possível de reabilitação social dos internos (Ferraz, 1998). Osório César trabalhou no Hospital Psiquiátrico do Juquery a partir da década de 1920, quando a laborterapia, até então o principal meio de tratamento utilizado, começava a entrar em declínio e os investimentos dos diretores voltavam-se para a instalação de um laboratório para estudo de anatomia patológica e de patologia expe- 
rimental no Hospital. Levado pelo seu interesse em arte e contaminado pela proximidade com os modernistas paulistas, o psiquiatra começou a ver aqui e ali - em folhas de papel, nas paredes, no chão -, traçados, linhas, formas que passou a recolher, catalogar e analisar sistematicamente, considerando-os trabalhos expressivos, com evidentes qualidades estéticas. Ele via nessas produções não somente expressões psicopatológicas da loucura, mas imagens que possuíam um inquietante parentesco com aquilo que os artistas modernos estavam produzindo. Nas palavras do autor: "A esthetica futurista apresenta varios pontos de contato com a dos manicômios. Não desejamos com isso censurar essa nova manifestação de arte;

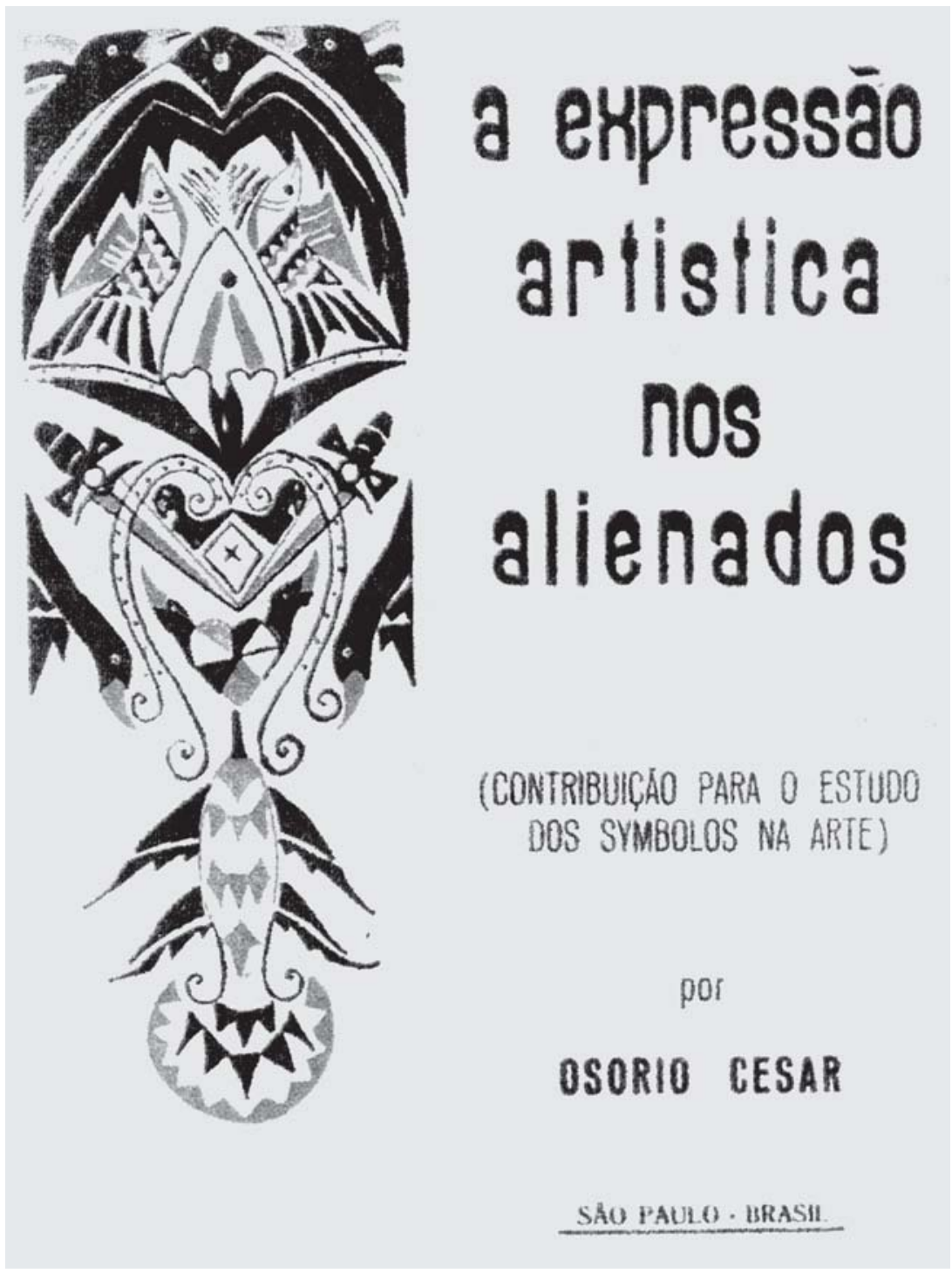


longe disso. Achamol-a muito interessante assim como a esthetica dos alienados. Ambas são manifestações de arte" (César, 1929, p.39).

Em 1929 Osório César publicou $A$ expressão artística dos alienados, falando de uma estética que inclui deformações e distorções figurativas, com caráter simbólico. No final dos anos 40 criou a Seção de Artes Plásticas, que se transformaria depois na Escola de Artes Plásticas do Juquery (Ferraz, 1998). O trabalho na Escola fundamentava-se em teorias psicológicas (principalmente Freud e Prinzhorn) e estéticas (com destaque para Dubuffet, que desenvolveu o conceito de arte bruta).

As preocupações de Osório César eram de caráter clínico e social. Para ele a finalidade primordial de um departamento de arte num hospital psiquiátrico era a reabilitação e a construção de alternativas fora do hospital. Ao criar a Escola de Arte, ele colocava o acento de sua proposta na profissionalização em arte, inserindo-a na esteira do pensamento que sustentava a laborterapia, mas enfatizando a idéia de uma perspectiva de vida fora do asilo. Esta deveria buscar-se em consonância com as riquezas que a loucura pode oferecer ao conjunto social, isto é, na potencialização de sua força e não em sua disciplinarização. Com tal perspectiva, Osório César promoveu exposições de trabalhos dos internos, visando "mostrar mais a parte social e a parte cultural, do que a parte psiquiátrica propriamente dita, dos alienados" (César, 20 out. 1948, citado em Ferraz, 1998, p.64).

Em 1954, por ocasião da Exposição dos Artistas Plásticos do Hospital de Juquery, no Museu de Arte de São Paulo, Menotti del Picchia escreveu um artigo apontando para uma das questões que os trabalhos dos internos traziam para a arte moderna:

Aquilo que muito pintor desesperadamente procura ... o louco atinge sem o mínimo esforço. Estes ficam artificialmente loucos para obter os valores plásticos que aqueles, justamente por ser loucos, alcançam. É claro que atingem essa perfeição com muito mais propriedade que os normais. (Menotti del Picchia, $15 \mathrm{abr}$. 1954, citado em Ferraz, 1998, p.90)

Nesse sentido, a proximidade entre arte moderna e loucura poderia indicar uma vertente fecunda para a experimentação artística e até mesmo constituir um índice da "verdadeira arte". É a posição de Flávio de Carvalho, para quem "a antropofagia como movimento literário, evoluiu para movimento científico e filosófico, tendo como objetivo a investigação das tendências da alma do homem e, como método, a observação, a pesquisa e o cálculo" (Carvalho, 26 jun.1930, citado em Leite, 1994, p.23).

Em 1932, com Di Cavalcanti e Antônio Gomide, Flávio de Carvalho fundou o Clube dos Artistas Modernos, um centro de divulgação das pesquisas empreendidas pelos artistas e um local de reu- 
nião animado por ateliês. Em 1933, organizou nesse clube o Mês dos Loucos e das Crianças, evento no qual foram expostas pela primeira vez obras de artistas internos do Hospital do Juquery. Talvez como fruto desse evento e das discussões que ali surgiram, Flávio de Carvalho publicou, em 1933, um artigo intitulado "Crianças artistas, doidos artistas" (Carvalho, set. 1933).

Esse interesse pelas produções marginais ao campo da arte esteve também explicitado no sugestivo título de um artigo publicado no Diário de S. Paulo, "A única arte que presta é a arte anormal" (Carvalho, 24 set. 1936). Nesse artigo o artista afirma que a arte é uma expressão das forças que plasmam e orientam o tempo em que ela é produzida, e como o século XX é o século das grandes descobertas psicológicas, quando o homem começa a conhecer a si mesmo e aos motivos de seu comportamento, a arte não poderia passar incólume a essa revolução: "Observa-se que o que o homem tem de mais interessante ou pertence aos domínios puros do pensamento ou provém desse mundo mórbido escondido. A arte na sua forma limite (tomando o sentido matemático de limite) é a que mais necessita dessa morbidez da alma e dessa pureza do pensamento" (p.34). Para Flávio de Carvalho, a arte que não atingisse esses domínios mal merecia ser nomeada como tal; seria uma arte medíocre, facilmente digerível, que agrada ao espírito médio. Mais provocativo ainda, o artista acrescentava que o problema estético de seu tempo pertencia, em grande parte, aos domínios da psicopatologia, já que o belo tornara-se um "bicho feio e difícil de amansar" (p.34). Por isso entendia que a arte anormal era a única arte que contava. Esta conteria valores artísticos profundos e estaria atravessada pelo que o homem tem de demoníaco e sublime, de raro, burlesco ou filosófico, enfim, algo que teria a espessura da vida (Carvalho, 24 set. 1936).

Contudo a associação entre arte e inconsciente serviu também para validar psicodiagnósticos feitos com base em expressões plásticas tanto de doentes como de artistas, o que culminaria no oposto da posição de Flávio de Carvalho. Da psicopatologia da expressão, e dos constantes trabalhos que tratam as obras como sintomas e os artistas como doentes, seria apenas um passo para a desqualificação seja da produção dos loucos, seja da arte moderna. Sobre essa idéia se pauta a afirmação de que a arte moderna é uma arte degenerada, produzida por insanos.

Essa visão das relações entre arte e loucura é parte integrante de um acontecimento marcante para o modernismo brasileiro: a exposição de Anita Malfatti, de 1917. As reações a essa exposição foram as mais controversas, e no centro delas estava a crítica de Monteiro Lobato. O escritor iniciou-a fazendo uma distinção: haveria duas espécies de artistas, uma veria normalmente as coisas e, a partir dessa percepção, faria 'arte pura'; a outra, anormalmente, e as respectivas obras seriam produtos do cansaço e do sadismo. Produ- 


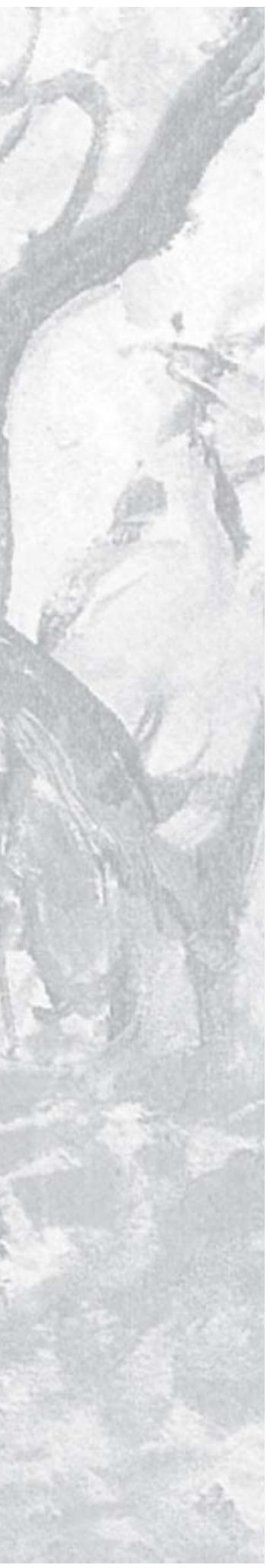

ções assim, segundo Lobato, estariam presentes em todos os períodos decadentes da história, e embora parecessem precursoras de uma arte por vir, "nada é mais velho que a arte anormal ou teratológica: nasceu com a paranóia e com a mistificação" (Lobato, 1964, p.46).

Então, Lobato tomou como aliados os psiquiatras para dizer que estes já estudavam havia muito tempo os desenhos que ornamentam as paredes dos manicômios; desenhos sinceros, segundo ele, produtos de cérebros transtornados por psicoses estranhas. Mas, para o crítico, quando esse tipo de obra se quer arte e é exposta publicamente, aí não há sinceridade mas apenas mistificação. Lobato via na exposição de Anita "acentuadíssimas tendências para uma atitude forçada no sentido das extravagâncias de Picasso e companhia" (Lobato, 1964, p.47), apesar de reconhecer que, por trás dessas obras "torcidas para a má direção", se notavam preciosas qualidades latentes e o talento vigoroso de uma artista que se deixou seduzir pelas teorias do que se chama arte moderna.

Percebemos que Lobato não estava julgando somente uma pintora, mas uma vertente da arte moderna. Para criticar essa nova estética, o escritor utilizou categorias clínicas, buscando distinguir percepções e expressões normais daquelas anormais. Se arte era representação da realidade, os traços e o uso das cores só poderiam refletir a percepção do artista, o que justificaria a discussão sobre a normalidade ou a anormalidade dessa percepção. Em suas palavras, para que sintamos de maneira diversa, cúbica ou futurista, é forçoso ou que a harmonia do universo sofra completa alteração, ou que o nosso cérebro esteja em 'pane' por virtude de alguma grave lesão. Enquanto a percepção sensorial se fizer normalmente no homem, um artista diante de um gato não poderá 'sentir' senão um gato (Lobato, 1964, p.47).

O episódio encarnou, de maneira bastante precisa, uma forma particular que a articulação entre as linhas da arte e da clínica acabaram ganhando na modernidade, conseqüência de se tomar o trabalho artístico como expressão imediata do mundo interno daquele que o produziu, de seus estados mentais e, portanto, como sintoma. Essa visão autorizava a prática de psicodiagnósticos com base nas produções plásticas, que levariam à descoberta do caráter mórbido do autor, prática que, realizada regularmente nas instituições psiquiátricas, ao ser aplicada a artistas consagrados revela-se inaceitável, tornando visível a violência que nela está embutida.

No Brasil das primeiras décadas do século XX, diante de obras produzidas por habitantes dos grandes asilos, o olhar psicopatológico insistia, querendo fazer ver aqui e ali uma desestruturação do ego, uma fragmentação da psique, uma fragilidade moral. Mas é certo também que, a partir do trabalho de Osório César e de sua ligação com os artistas modernos, insinuou-se uma alteração nas 
relações entre arte, clínica e loucura, que ganharia consistência no final da década de 1940, quando as obras produzidas no Ateliê de Pintura da Seção de Terapêutica Ocupacional do Hospital do Engenho de Dentro, no Rio de Janeiro, passaram a compor o território de composição entre esses campos. Entraria em cena, então, uma concepção de arte que, na radicalização da proposta moderna de articular arte e vida, viria produzir uma inflexão na paisagem que vínhamos acompanhando e uma reconfiguração do território no qual arte, clínica e loucura se atravessam.

\section{Uma paisagem-dobradiça: inflexões rumo a novas configurações do território}

Avançando cerca de duas décadas em relação aos primeiros encontros entre psiquiatria, psicanálise e modernismo, encontramos no Rio de Janeiro uma nova composição entre artistas, clínicos e pacientes psiquiátricos. A articulação entre arte, clínica e loucura ganhou novos contornos em uma aventura intelectual e sensível, das mais belas e potentes desenvolvidas no Brasil, por Nise da Silveira, médica psiquiatra movida pela força de sua indignação com o tratamento oferecido aos pacientes dos hospitais psiquiátricos.

Quando iniciou seu trabalho no Centro Psiquiátrico Nacional, do Rio de Janeiro, em 1946, "a terapêutica ocupacional era considerada um método subalterno, destinado apenas a 'distrair' ou contribuir para a economia hospitalar” (Silveira, 1992, p.16). A prática corrente da psiquiatria científica baseava-se em eletrochoques e lobotomias. Nise opôs-se frontalmente a tais procedimentos. Desde o início colocou-se num embate contra a psiquiatria de seu tempo e dedicou-se a pesquisa e desenvolvimento de outras terapêuticas, partindo inicialmente da organização do Setor de Terapêutica Ocupacional daquele hospital.

Desde o início a psiquiatra imprimiu ao trabalho uma orientação própria: a terapêutica ocupacional, entendida por ela em sentido amplo, tinha como objetivo encontrar atividades que servissem aos doentes como meios de expressão. Seria preciso partir do nível não verbal. É aí que se insere a terapêutica ocupacional, oferecendo atividades que permitam a expressão de vivências não verbalizáveis por aquele que se acha mergulhado na profundeza do inconsciente (Silveira, 1981, p.102). Entre os vários setores ocupacionais (encadernação, costura, música etc.), os ateliês de pintura e modelagem se destacaram, passando a receber um investimento diferenciado por parte da psiquiatra. Nise afirmava que as atividades ali desenvolvidas permitiam, graças à livre expressão, acesso mais fácil ao mundo interno do esquizofrênico, em geral muito hermético.

Com o intuito de enriquecer essa experiência, foram introduzidos, no atendimento e na pesquisa, profissionais variados, in- 
cluindo artistas plásticos e músicos. Durante o desenvolvimento de seu trabalho, Nise da Silveira manteve sempre um diálogo aberto com o campo das artes, demonstrando uma excepcional capacidade de articulação e colocando em questão a univocidade da fala e do saber médicos sobre a loucura.. Mediante essas parcerias, os trabalhos realizados nos ateliês do Centro Psiquiátrico foram conectados ao mundo das artes, possibilitando que outros olhares viessem banhálos de outros significados, tornando visíveis traços e linguagens que



Fernando Diniz. Tapete digital, 1989; guache sobre tecido, 254,2×249cm. Acervo do Museu de Imagens do Inconsciente 
5 A primeira exposição das obras do Museu de Imagens do Inconsciente aconteceu em 1947, no Ministério da Educação, no Rio de Janeiro. Seguiu-se a ela uma dezena de exposições, entre elas uma no Museu de Arte Moderna de São Paulo, em 1949, e outra em 1956, no próprio Museu inaugurado em 1952, além de mostras no $1^{\mathrm{o}}$ Congresso

Internacional de

Psiquiatria, em Paris (1950), e no $2^{\mathrm{o}}$

Congresso

Internacional de Psiquiatria, em Zurique (1957). Nos anos subseqüentes as obras do Museu participaram da $16^{\mathrm{a}}$ Bienal de São Paulo, em 1981, e da mostra Redescobrimento Brasil + 500, em 2000 .

\footnotetext{
6 Em 1951, no texto

"Forma e personalidade", Pedrosa associou o que chamava de 'arte virgem' à 'arte bruta' e definiu os produtores desse tipo de arte como "homens que não conseguem contemplar o mundo sem estremecer, comovidos" (Pedrosa, 1996b, p.196).
}

escapam ao olhar do especialista médico. As inúmeras exposições das obras do acervo, realizadas no Brasil e exterior ${ }^{5}$, a criação do Museu de Imagens do Inconsciente, a participação de artistas e críticos e a atmosfera cultural em que se desenvolveu essa aventura teórico-prática foram estratégias que colaboraram para que as obras e seus artistas, aos poucos, se desprendessem de sua origem psiquiátrica para fazer seu percurso no universo cultural, contribuindo para a transformação do pensamento sobre o louco e a loucura.

A partir do trabalho de Nise da Silveira passamos a entender que a produção plástica dos psicóticos ou de qualquer um vai muito além das representações distorcidas e veladas dos conteúdos pessoais reprimidos. Como diz a autora, "uma pintura quase nunca será o mero reflexo de sintomas" (Silveira, 1981, p.51). Ao pintar, o indivíduo não somente expressa a si mesmo, mas cria algo novo, produz um símbolo, e essa produção tem efeitos de transformação tanto na realidade psíquica como na realidade compartilhada.

O encontro de Nise da Silveira com o crítico de arte Mário Pedrosa fortaleceu a perspectiva com que a psiquiatra vinha trabalhando, potencializando a experiência desenvolvida no Museu de Imagens do Inconsciente. Para o crítico, a iniciativa de organizar, para os internos de uma instituição psiquiátrica, um Setor de Terapêutica Ocupacional com ênfase nas atividades artísticas e as exposições daí decorrentes teve enorme relevância cultural e estética, além de ter sido marcante no desenvolvimento de seu pensamento. $\mathrm{O}$ crítico identificou essa iniciativa de Nise da Silveira como um acontecimento dos mais importantes, no campo cultural e artístico do Brasil, anteriores à primeira Bienal de São Paulo (1951), acontecimento que interessa de perto às atividades de criação artística em geral, por ter sido responsável por romper com velhos preconceitos intelectualistas, concepções convencionais e acadêmicas quanto à natureza do fenômeno artístico, e componente importante do solo no qual germinou a arte contemporânea brasileira (Pedrosa, 1995).

O encontro de Mário Pedrosa com o que chamou de 'arte virgem $^{\prime 6}$ ou mais especificamente, com a experiência do Setor de Terapêutica Ocupacional do Centro Psiquiátrico Nacional, aconteceu no início de sua carreira como crítico de arte. Em 1947, quando começava a se dedicar com regularidade à crítica de artes plásticas, proferiu uma conferência, "Arte, necessidade vital” (Pedrosa, 1996a), por ocasião do encerramento da primeira exposição das produções realizadas no ateliê daquele setor. Para Otília Arantes (1996), esse é um dos textos mais sugestivos e originais de toda a produção crítica de Pedrosa. Nele, além de representar um marco no debate estético, o crítico enfatizou o caráter educativo e terapêutico da arte e apresentou uma síntese dos principais temas que o ocupariam até 


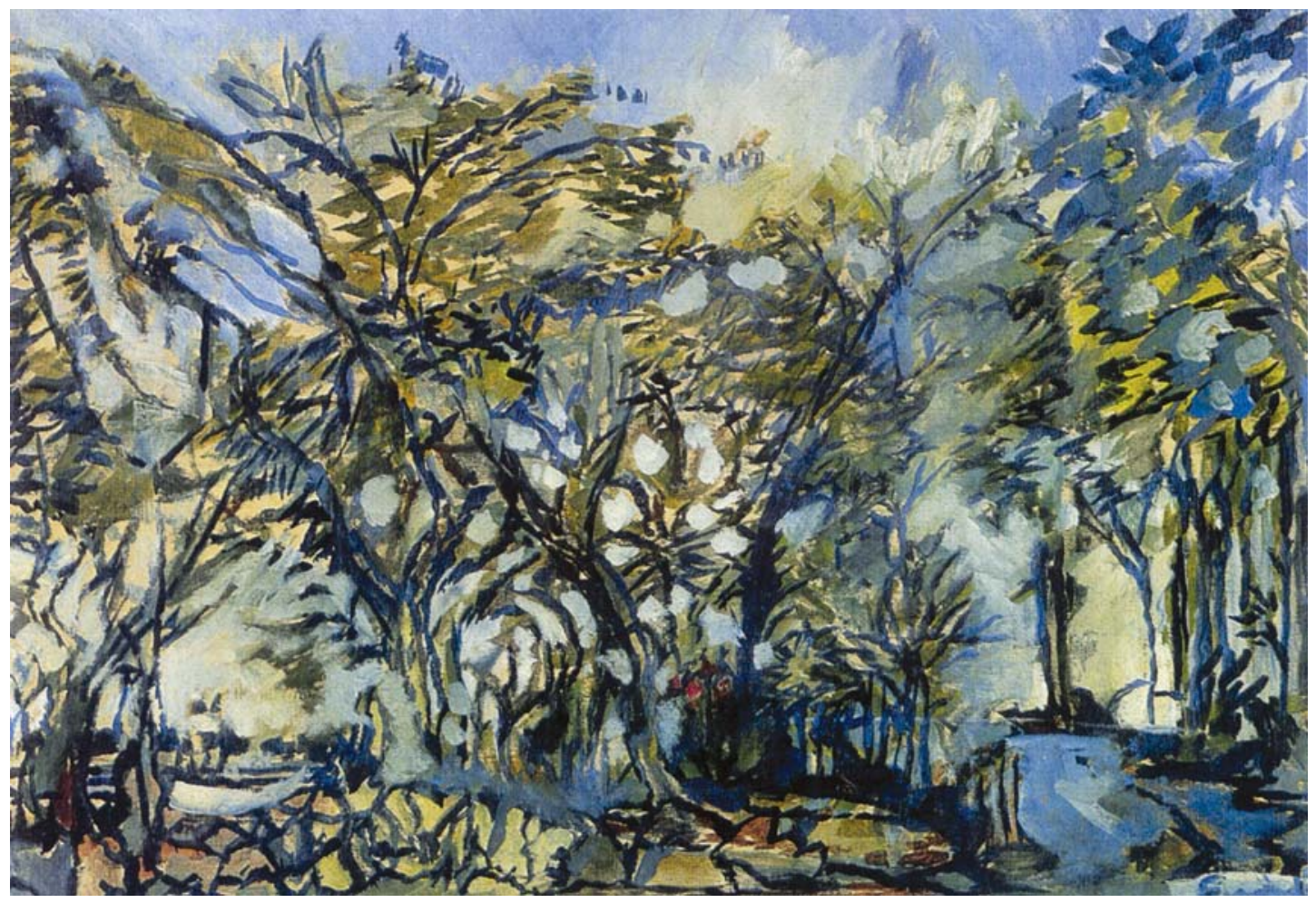

Emygdio de Barros. Sem título, 1969; óleo sobre tela, 43×60cm. Acervo do Museu de Imagens do Inconsciente

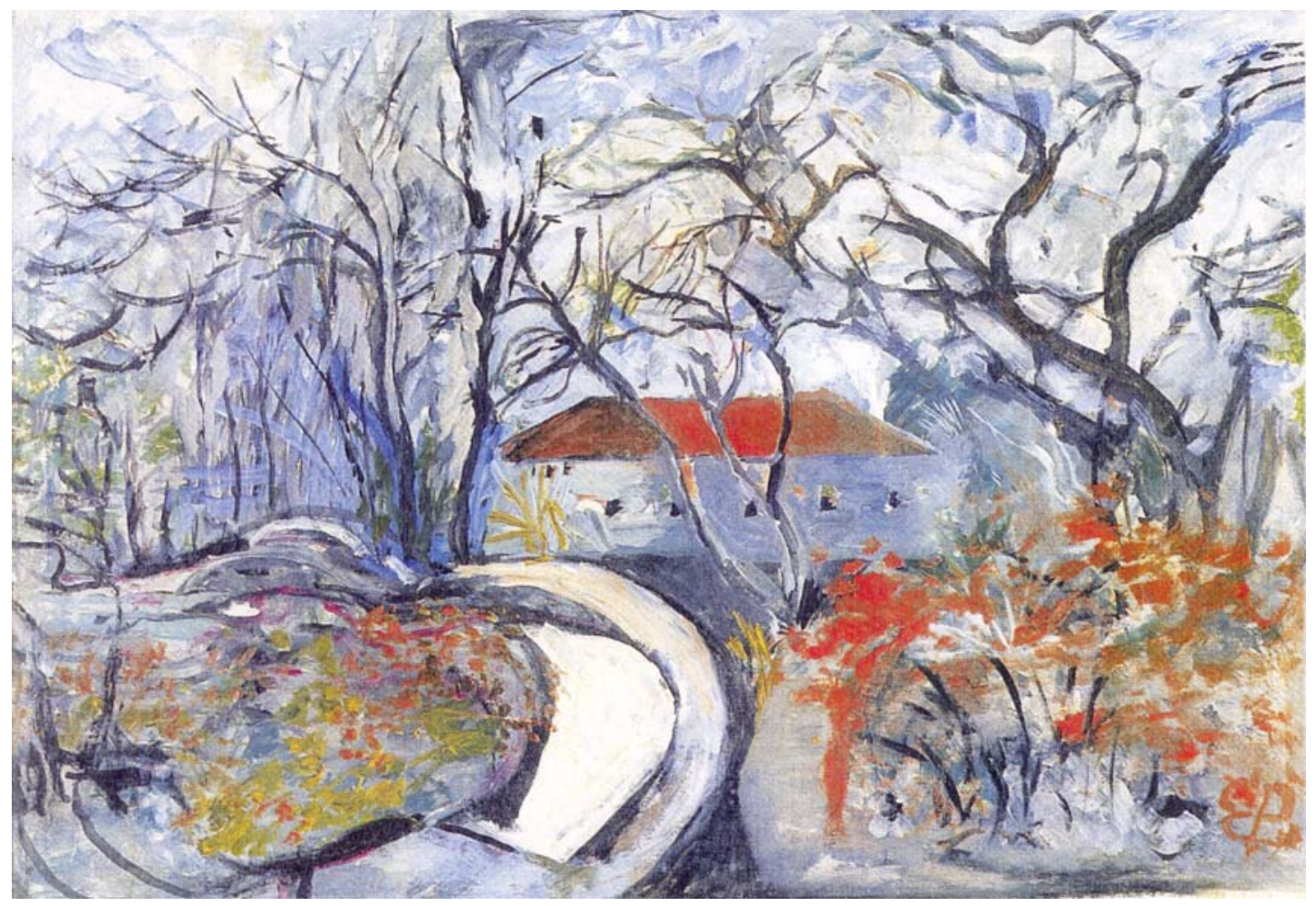

Emygdio de Barros. Sem título, 1969; óleo sobre tela, 50x70,5cm. Acervo do Museu de Imagens do Inconsciente 
o final de sua vida. No artigo, Mário Pedrosa empreende um percurso na tentativa de surpreender a arte em seus fundamentos vitais e psíquicos. Inicia argumentando que a perplexidade e o estranhamento que cercavam uma exposição como aquela se devia a uma incompreensão do que fosse arte, fruto de um preconceito intelectualista que tomava a arte por uma atividade à parte, excepcional e o artista, por um ser envolto em um halo místico. E mais: nessa perspectiva a Arte, que não perdeu a 'maiúscula', só interessava pelo seu resultado, a obra de arte, objeto de consagração, fetiche da sociedade capitalista.

No entanto Pedrosa afirmava que os artistas modernos haviam assimilado as conquistas relativas ao que chamou de 'expressão desinteressada' e que por isso foram, muitas vezes, identificados aos primitivos e aos loucos, ou apontados como infantis ou mistificadores. Mas de tudo isso resultou a elaboração de um novo conceito de arte, que o crítico defenderia. Relacionando a atividade criadora a processos inconscientes, e entendendo que manifestações de ordem poética não são produtos somente de altas culturas intelectuais e científicas, mas têm caráter universal, o crítico defendia:

A atividade artística é uma coisa que não depende de leis estratificadas, frutos da experiência de apenas uma época na história da evolução da arte. Essa atividade se estende a todos os seres humanos, e não é mais ocupação exclusiva de uma confraria especializada que exige diploma para nela se ter acesso. A vontade de arte se manifesta em qualquer homem de nossa terra, independente do seu meridiano, seja ele papua ou cafuzo, brasileiro ou russo, letrado ou iletrado, equilibrado ou desequilibrado. (Pedrosa, 1996a, p.46)

A arte seria, nessa visão, uma questão de sensação que toma o corpo com a decaída da atividade consciente, o que faz que se desprendam de nós partes que usualmente não tomaríamos como nossas, borrando os limites que a atividade da consciência não cessa de traçar entre 'eu' e 'não eu', 'sujeito' e 'objeto'. Para Pedrosa não poderia haver manifestação criadora de qualquer ordem se aspirações íntimas, 'anomalias', estivessem embotadas por uma "suficiente adaptação ao meio" (Pedrosa, 1996a, p.49).

Assim, a arte passa a ser entendida não como exceção inatingível, mas como fenômeno verdadeiramente vital - criação que reproduz o milagre da vida - e que, portanto, deveria estar acessível para qualquer um. Para o crítico, não deveria haver barreiras para o mundo encantado das formas, que é comum a todos os homens indistintamente. Portanto todos deveriam aprender a pintar, esculpir e desenhar como se aprende a ler e escrever. O efeito da realização dessas atividades se poderia sentir também nos doentes 
mentais, "curando-os ou alentando-os, atraindo-os a vir de novo cá fora, no nosso mundo bruto e feio, com mensagens que por vezes são decifráveis e brilham, fulminantes, fugazes, como lampejos" (Pedrosa, 1996a, p.56). Na perspectiva de Mário Pedrosa, o efeito de produção subjetiva que o fazer artístico pode ter não desmerece o produto ou resultado material desse fazer. Para ele, a obra não é tudo (nem mesmo o mais importante no fenômeno artístico), e a qualidade estética dos trabalhos não é inversamente proporcional aos efeitos clínicos que poderia engendrar. Qualquer pessoa que se dedique a essas ocupações que possibilitam um contato mais delicado e sutil com o mundo, as coisas e os outros seres termina por enriquecer-se e transformar-se.

A experiência desenvolvida no Museu de Imagens do Inconsciente produziu uma importante inflexão no pensamento sobre as contribuições da arte para a clínica e sobre as relações entre arte, loucura e subjetividade. Essa inflexão abre o território que estamos cartografando para novas configurações, fazendo que este possa abarcar as transformações contemporâneas no campo da arte e da clínica, produzindo uma nova articulação entre os campos.

\section{Arte, clínica e loucura no contemporâneo: apontamentos}

A partir da segunda metade do século XX a atividade artística deslocou o acento das obras para a produção de acontecimentos, ações e experimentações (Favaretto, 1994). Muitas formas de arte não se materializam numa coisa; existem apenas no momento em que as experimentamos e depois se desfazem com a efemeridade daquilo que é mais da ordem da duração que da extensão. Já os produtos materiais dessas experimentações abandonam a designação de obras de arte e passam a ser chamados indistintamente de objetos.

De alguma maneira, o desafio que atravessa o projeto estético contemporâneo torna-se o de "presentificar o excesso do impresentificável, utilizando o informe como indício desse mesmo impresentificável" (Lyotard, 1963, citado em Pelbart, 1998, p.66). Ao pedir uma estética fragmentária, complexa, feita de fluxos, um tal projeto atravessa, também, como o indica Peter Pelbart, algumas experimentações estéticas que se fazem na fronteira com a clínica ou com a patologia e que evocam dor e colapso, mas também metamorfoses e intensidades sem nome. Talvez seja por isso que a produção impressionante e descomunal de Arthur Bispo do Rosário possa ser analisada no contexto da arte contemporânea, tal como o fez Frederico Morais (1990), ao afirmar: "Bispo é tosco, direto e rude, pois que lida com materiais pobres, os 'materiais da vida'. Ele é um fazedor de coisas, um demiurgo, alguém capaz de arrancar as coisas de sua banalidade e de sua concretude material para dar-lhes um novo significado, como Marcel Duchamp" (p.22). 
Porém no campo clínico temos assistido, nos últimos 30 anos, à construção de um grande número de práticas nas quais atividades artísticas participam de um processo de transformação das instituições psiquiátricas e de questionamento e redefinição do lugar da loucura (Lima, 1997). Em uma infinidade de experiências que tiveram lugar a partir da reforma psiquiátrica brasileira, busca-se, através da arte, tematizar as oposições saúde e doença, normal e patológico, loucura e sanidade. Hoje, as práticas de desinstitucionalização atravessam os muros do hospital, invadem a cidade e passam a intervir nas redes sociais e na cultura, buscando desfazer 'manicômios mentais'. Um número cada vez maior de ações territoriais visa construir novas possibilidades no campo das trocas sociais e da produção de valor, buscando criar novas comunidades e outras sociabilidades.

Nessas experiências a arte está presente como um instrumento de enriquecimento das vidas, de descoberta e ampliação de potencialidades, de acesso a bens culturais (Nicácio, 1994). A clínica, nesta

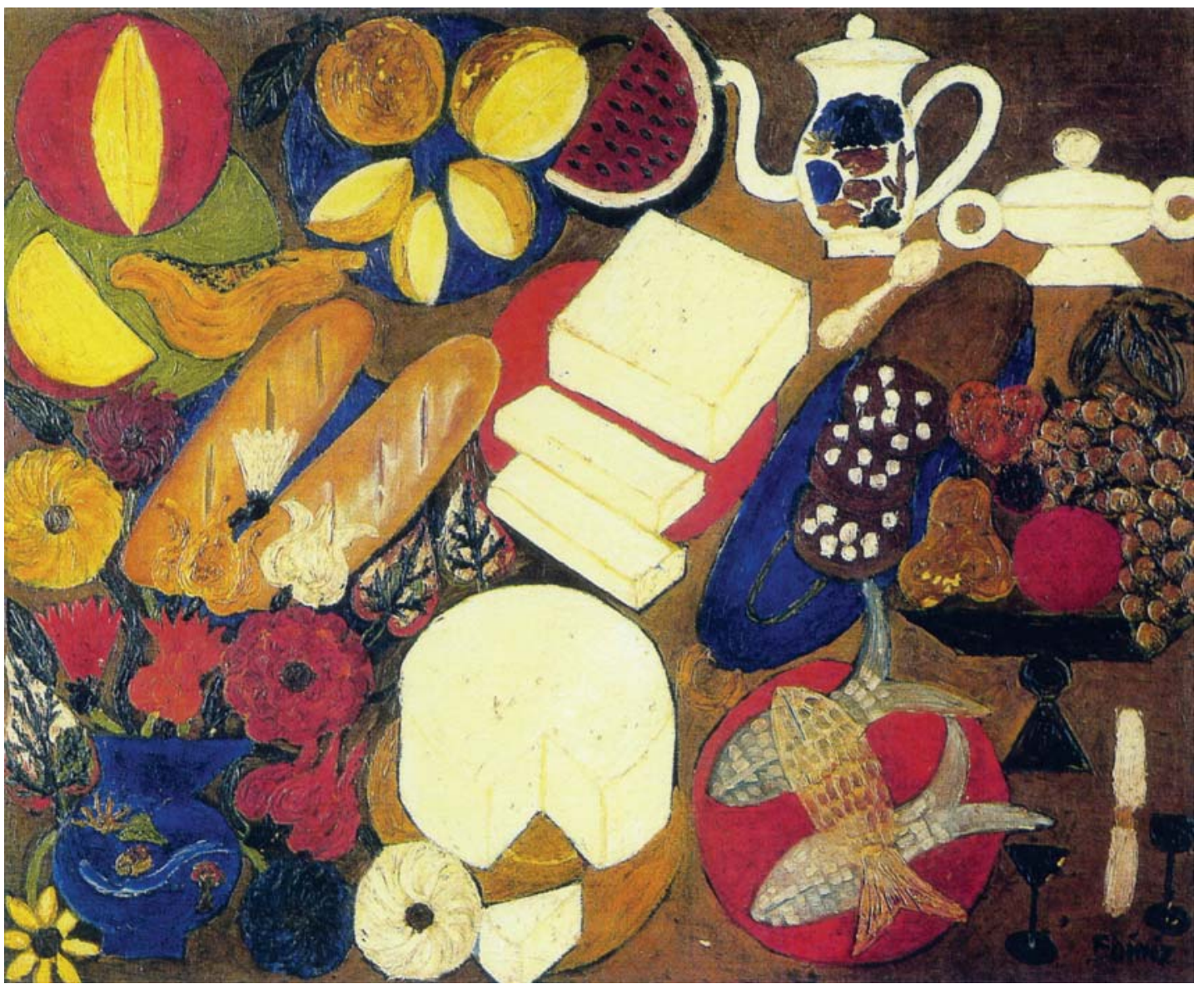

Fernando Diniz. Sem título, 1954; óleo sobre tela, 64,5×80cm. Acervo do Museu de Imagens do Inconsciente 
nova configuração, se faz no território da cidade - e não no interior de grandes asilos - e não está voltada para a remissão de sintomas, mas para a promoção de processos de vida e de criação que comportam uma outra saúde, não uma saúde inteiriça, perfeita, acabada, funcionando bem demais, mas uma saúde frágil, marcada por um inacabamento essencial que, por isso mesmo, pode se abrir para o mundo; uma saúde que consegue ser vital mesmo na doença (Deleuze, 1997). Para essa clínica, cada sujeito, ao construir um objeto, pintar uma tela, cantar uma música, faz algo mais que expor a si mesmo e o próprio sofrimento. Ele realiza um fato de cultura. Os produtos dessas experiências estéticas podem ser materiais e imateriais: obras, acontecimentos, efeitos sobres os corpos, novas subjetividades. O sentido de fazer obra aqui é o de encontrar ferramentas para a recomposição de universos existenciais e para uma produção mutante de enunciação (Guattari, 1992).

Chegamos ao final de nossa viagem por esse território povoado de personagens, imagens e enunciados entendendo que, ao menos no Brasil - recorte que elegemos para estudar essas relações -, não houve um encerramento da implicação entre os campos da arte, da

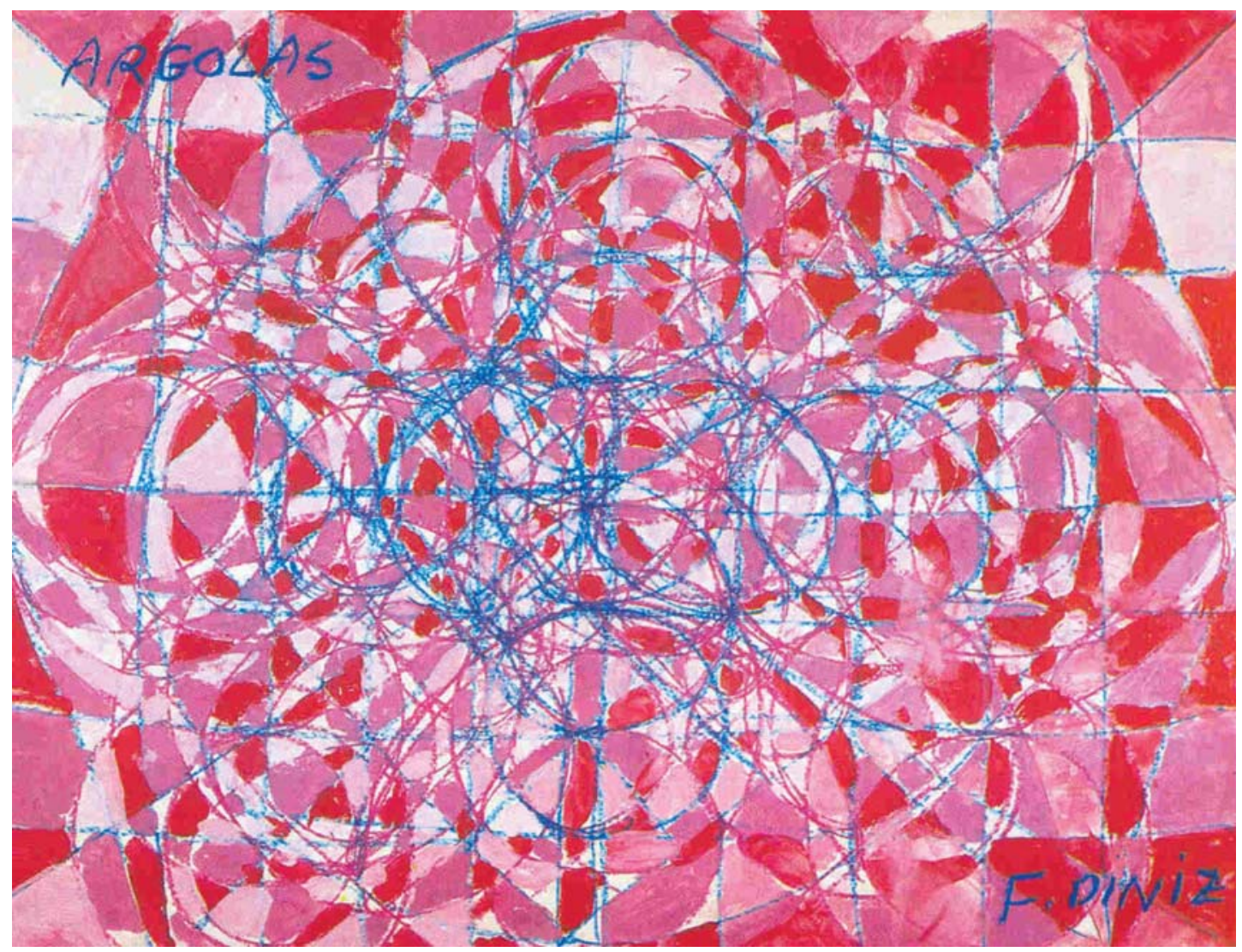

Fernando Diniz. Argolas, 1987; guache sobre papel, 56,5×74cm. Acervo do Museu de Imagens do Inconsciente 


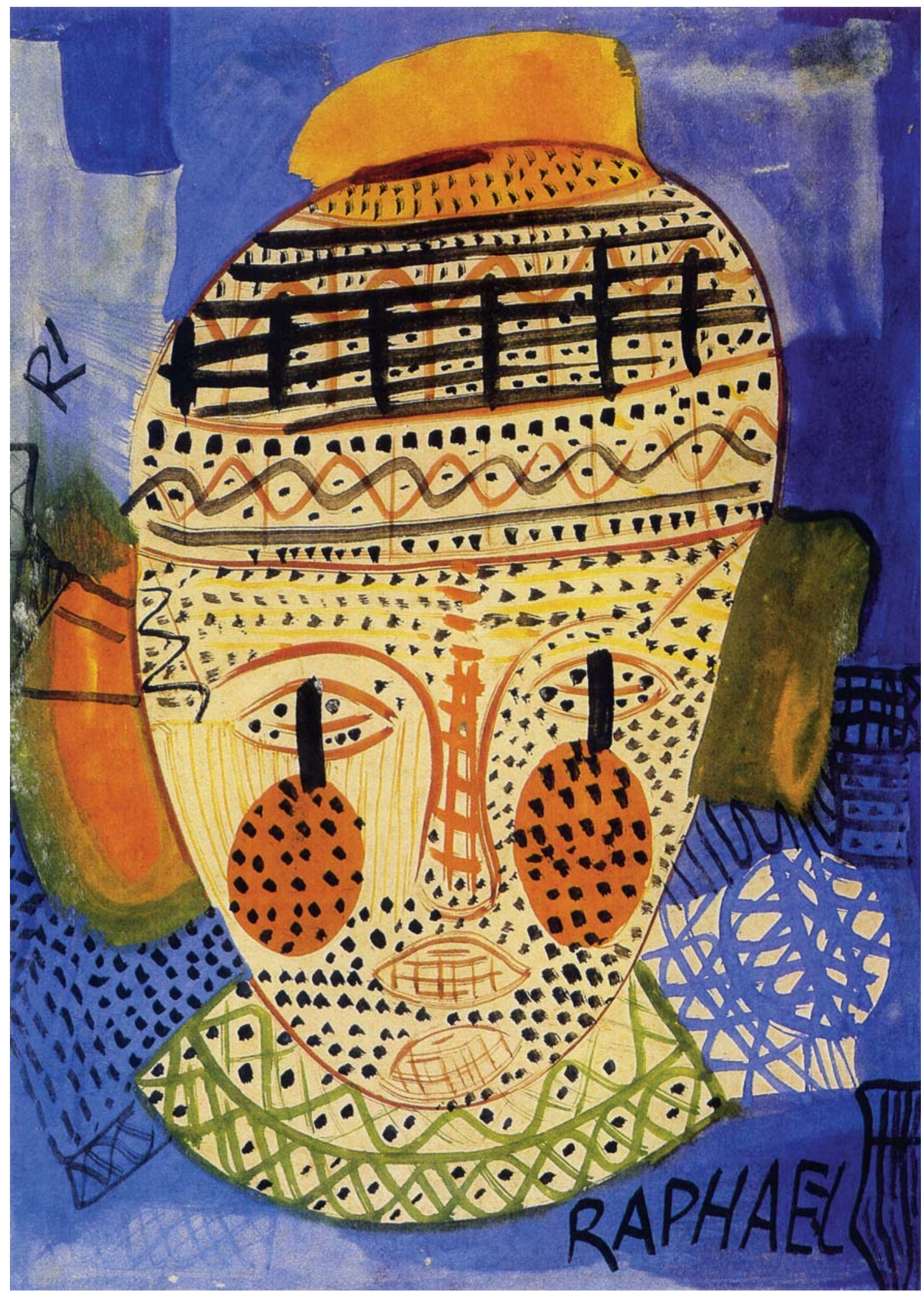

Raphael Domingues. Sem título, 1948; guache e nanquim sobre papel, $32,5 \times 23,5 \mathrm{~cm}$. Acervo do Museu de Imagens do Inconsciente 
clínica e da loucura, mas um deslocamento de suas coordenadas. $\mathrm{O}$ diálogo entre arte, loucura e clínica, tal como se deu na modernidade, acabou por produzir mutações em cada um dos campos, como se, de alguma forma, arte e loucura, como blocos monolíticos e isolados do conjunto das práticas sociais, houvessem sido implodidos e passassem a se cruzar em múltiplas conexões, em outros tantos territórios.

Assim, ainda que cada uma dessas esferas tenha mantido sua singularidade, elas não cessaram de interferir entre si e sofrerem mutações e deslizamentos, às vezes sutis. Nesse processo, a loucura pode encontrar uma linha de fuga que extrapola o campo de uma patologia da interioridade; a arte, uma outra linha que pode levá-la para espaços que extrapolam o campo de uma atividade delimitada e autônoma; a clínica, uma terceira linha, que pode levá-la a extrapolar o domínio do patológico e da instituição asilar. Para essa clínica não interessa o sistema da arte ou a arte institucionalizada, mas sim procedimentos artísticos associados a uma arte do efêmero e do inacabado que comporte as desterritorializações e os desequilíbrios dos sujeitos dos quais se ocupa. Já a arte contemporânea não está interessada na loucura como entidade psicopatológica, mas numa certa forma de produção 'esquizo', uma desterritorialização que fica adensada nos esquizofrênicos, o que faz que muitas experiências artísticas possam comportar um tipo de experiência limite e preparar uma relação com aquilo que uma cultura rejeita (Pelbart, 2000).

Quanto aos sujeitos criadores - que produzem suas invenções em maior ou menor proximidade com os abismos da loucura -, eles continuam agarrados por um conjunto de impossibilidades, escavando saídas, criando possibilidades, buscando construir linhas de fuga (Deleuze, 1992) que, por fim, servem para todos nós. 


\section{REFERÊNCIAS BIBLIOGRÁFICAS}

Aguiar, Flávio

1975

Arantes, Otília

Beatriz Fiori 1996

Arrigucci Jr., Davi 1996

Assis, Machado de 1996

Assis, Machado de 1977

Assis, Machado de 1998

Barbosa, Ana Mae 1998

Carvalho, Flávio R. 24 set. 1936

Carvalho, Flávio R. set. 1933

Carvalho, Flávio R. 26 jun. 1930

César, Osório 20 out. 1948

César, Osório 1929

Coelho, Teixeira 2002

Deleuze, Gilles 1997

Deleuze, Gilles 1992

Deleuze, Gilles;

Guattari, Fèlix

2001

Favaretto, Celso 1994

Ferraz, Maria

Heloísa Toledo 1998

Foucault, Michel 1995
Os homens precários.

Porto Alegre: A Nação; IEL.

Mário Pedrosa, um capítulo brasileiro da teoria da abstração (Prefácio). In: Arantes, Otilia Beatriz Fiori (Org.). Mario Pedrosa. Forma e percepção estética: textos escolhidos II. São Paulo: Edusp. p.13-38.

Obras do Acaso (Apresentação). In: Assis, Machado de. Terpsícore. Apres. Davi Arrigucci Jr. São Paulo: Boitempo. 1a. ed., 1886.

Terpsícore. Apres. Apres. Davi Arrigucci Jr.

São Paulo: Boitempo. 1a. ed., 1886.

$O$ alienista.

São Paulo: Ática. 1a. ed., 1882.

Contos: uma antologia / Machado de Assis.

Sel., introd. e notas de John Gledson. São Paulo: Companhia das Letras.

Prefácio. In: Ferraz, Maria Heloísa Toledo.

Arte e loucura: limites do imprevisível. São Paulo: Lemos.

A única arte que presta é a anormal.

Diário de S. Paulo, São Paulo.

Crianças artistas, doidos artistas.

Rumo, Rio de Janeiro, n.5, p.29.

O futurismo na architetura.

Diário da Noite, São Paulo.

Entre os alienados a forma mais prática: ‘a evasao dos próprios sentimentos é a arte decorativa'. Entrevista concedida ao Diário de São Paulo, São Paulo.

A expressão artística nos alienados: contribuição para o estudo dos symbolos na arte. São Paulo: Officinas Graphicas do Hospital do Juquery.

A arte não revela a verdade da loucura, a loucura não detém a verdade da arte. In: Antunes, Eleonora H.; Barbosa, Lucia Helena S.; Pereira, Lygia Maria de F. (Org.). Psiquiatria, loucura e arte: fragmentos da história brasileira. São Paulo: Edusp. p.147-163.

Crítica e clínica.

São Paulo: Ed. 34.

Conversações.

São Paulo: Ed. 34.

O que é a filosofia.

São Paulo: Ed. 34.

Apresentação. In: Fabrini, Ricardo. O espaço de Lygia Clark. São Paulo: Atlas.

Arte e loucura: limites do imprevisível.

Pref. Ana Mae Barbosa. São Paulo: Lemos Ed.

História da loucura na idade clássica.

São Paulo: Perspectiva. 
Gledson, John

1998

Guattari, Felix 1992

Lafora, Gonzalo 1927

Leite, Rui Moreira 1994

\section{Lima, Elizabeth}

Araújo

1997

Lobato, Monteiro 1964

Lobo, Luiza 1993

Lopes, Lucia

Leite R.P.

2001

Lyotard,

Jean-François

1963

Marques, Maria

Valquiria Alves

1993

Morais, Frederico 1990

Nicácio, Maria

Fernanda 1994

Pedrosa, Mário 1996a

Pedrosa, Mário 1996b

Pedrosa, Mário 1995

Pelbart, Peter Pál 2000

Pelbart, Peter Pál 1998
Introdução. In: Assis, Machado de. Contos: uma antologia / Machado de Assis. Sel., introd. e notas de John Gledson. São Paulo: Companhia das Letras.

Caosmose: um novo paradigma estético.

Rio de Janeiro: Ed. 34.

Don Juan, los milagros y otros ensayos.

Madrid: Biblioteca Nueva.

Flávio de Carvalho: entre a experiência e a experimentação.

Tese (Doutorado) - Escola de Comunicações e Artes, Universidade de São Paulo, São Paulo.

Clínica e criação: a utilização de atividades em instituições de saúde mental.

Dissertração (Mestrado) - Programa de Estudos Pós-graduados em

Psicologia Clínica, Pontifícia Universidade Católica de São Paulo,

São Paulo.

Paranóia ou mistificação. In: Brito, Mário da Silva.

História do modernismo brasileiro. Rio de Janeiro: Civilização Brasileira. p.46-47. 1a. ed., 1919.

As metáforas do humor em Machado de Assis. In: Lobo, Luiza. Crítica sem juízo: ensaios. Rio de Janeiro: Francisco Alves. p.95-102.

Machado de Assis de A a X.

São Paulo: Ed. 34.

Resposta à questão: o que é o pós-moderno?

Arte em Revista, São Paulo, n.7, p.96.

Escritos sobre um Qorpo.

São Paulo: Annablume.

A reconstrução do universo segundo Arthur Bispo do Rosário. In: Registros de minha passagem pela terra: Arthur Bispo do Rosário. (Catálogo). São Paulo: Museu de Arte Contemporânea da USP (MAC). p.17-25.

O processo de transformação da saúde mental em Santos: desconstrução de saberes, instituições e cultura. Dissertação (Mestrado) - Programa de Estudos Pós-graduados em Ciências Sociais, Pontifícia Universidade Católica de São Paulo, São Paulo.

Arte, necessidade vital. In: Arantes, Otilia Beatriz Fiori (Org.).

Mario Pedrosa. Forma e percepção estética: textos escolhidos II.

São Paulo: Edusp. p.41-58. 1a. ed., 1947.

Forma e personalidade. In: Arantes, Otilia Beatriz Fiori (Org.).

Mario Pedrosa. Forma e percepção estética: textos escolhidos II.

São Paulo: Edusp. p.179-220. 1a. ed., 1951.

A Bienal de cá pra lá. In: Arantes, Otilia Beatriz Fiori (Org.). Mario Pedrosa. Política das artes: textos escolhidos I. São Paulo: Edusp. p.216-84. 1a. ed., 1970.

A vertigem por um fio.

São Paulo: Fapesp; Iluminuras.

Teatro nômade.

Revista de Terapia Ocupacional da USP, São Paulo, v.9, n.2, p.62-69. 
Picchia, Menotti del. Pintura de loucos.

15 abr. 1954 A Gazeta, São Paulo.

Qorpo-Santo, Joaquim José

Campos Leão

2000

Qorpo-Santo, Joaquim José

Campos Leão

1969

Qorpo-Santo, Joaquim José

Campos Leão

1877

Rolnik, Suely 1989

Roudinesco,

Elisabeth

8 abr. 2001

Silveira, Nise da

1992

Silveira, Nise da 1981

Teixeira, Ivan

1987
Poemas. Org. Denise Espírito Santo.

Rio de Janeiro: Contra Capa.

As relações naturais e outras comédias. Fixação do texto, estudo crítico e notas de Guilhermino César Porto Alegre: Ed. FF-UFRS.

Ensiqlopèdia ou seis mezes de huma enfermidade.

Porto Alegre: Tipografia Qorpo-Santo.

Cartografia sentimental: transformações contemporâneas do desejo. São Paulo: Estação Liberdade.

'Ler o delírio' acaba de sair na França.

Folha de S. Paulo, São Paulo. Caderno Mais!, p.19.

O mundo das imagens.

São Paulo: Ática.

Imagens do inconsciente.

Rio de Janeiro: Alhambra.

Apresentação de Machado de Assis.

São Paulo: Martins Fontes.

Recebido para publicação em junho de 2006.

Aprovado para publicação em setembro de 2006. 